\title{
Pengembangan multimedia pembelajaran interaktif materi sistem organisasi kehidupan berbasis game edukasi
}

\author{
M. Miftakhul Huda, Munzil*, Metri Dian Insani \\ Universitas Negeri Malang, Jl. Semarang No. 5 Malang, Jawa Timur, Indonesia \\ *Penulis korespondensi, Surel: munzil.fmipa@um.ac.id
}

Paper received: 01-03-2021; revised: 15-03-2021; accepted: 31-03-2021

\begin{abstract}
The aim of this research was to develop interactive learning multimedia in living organization system material on educational game. The validation test included media validation and material validation. The media validation was carried out by media expert, included of one physics lecturer and one natural science teacher, whereas the material validation was carried out by material expert, included of one biology lecturer. The legibility test in small group was carried out to 15 students grade VIII who had learned living organization system material. Based on the evaluation result, the developed interactive learning multimedia has proven valid and fulfilled very worthy criteria to be used.
\end{abstract}

Keywords: multimedia; living organization system; educational game

\begin{abstract}
Abstrak
Penelitian ini bertujuan untuk menghasilkan multimedia pembelajaran interaktif pada materi sistem organisasi kehidupan berbasis game edukasi. Uji kelayakan dilakukan melalui validasi media, materi, dan uji keterbacaan. Validasi media oleh satu dosen Fisika dan satu guru IPA SMP, validasi materi oleh satu dosen biologi, dan uji keterbacaan pada 15 siswa kelas VIII SMP. Hasil penelitian menunjukkan bahwa multimedia yang dikembangkan sangat valid dan sangat layak untuk digunakan.
\end{abstract}

Kata kunci: multimedia; sistem organisasi kehidupan; game edukasi

\section{Pendahuluan}

IPA merupakan kumpulan dari pengetahuan yang tersusun secara sistematis (Mariana \& Praginda, 2009: 26). Pembelajaran IPA yang dilakukan juga bukan hanya menyajikan kumpulan pengetahuan saja, melainkan juga proses mencari tahu yang sistematis (Trianto, 2007: 99). Proses ini dapat dilakukan dengan pemberian pengalaman langsung kepada siswa, sehingga terbentuk pembelajaran yang berpusat pada siswa sesuai dengan kurikulum 2013. Salah satu materi IPA kelas VII semester I adalah sistem organisasi kehidupan dalam KD 3.4. KD ini menyatakan bahwa siswa harus mampu mendeskripsikan keragaman pada sistem organisasi kehidupan mulai dari tingkat sel sampai organisme, serta komposisi utama penyusun sel. Pembelajaran pada materi ini mengantarkan siswa untuk memahami hierarki kehidupan dan saling keterkaitan antar komponen penyusunnya mulai dari tingkat sel, jaringan, organ, sistem organ, sampai menyusun suatu organisme.

Berdasarkan hasil wawancara dengan guru kelas VII di salah satu SMP Kota Malang diperoleh fakta bahwa pemahaman siswa terhadap materi sistem organisasi kehidupan masih belum maksimal. Hasil belajar menunjukkan bahwa siswa mendapat nilai dibawah KKM dengan rata-rata nilai 59,70 serta tingkat kelulusan siswa pada materi tersebut hanya mencapai $20,71 \%$. Pengajaran yang biasa digunakan yaitu ceramah menggunakan media gambar dua dimensi. Hal tersebut belum dapat mengatasi kesulitan siswa memahami konsep-konsep sistem organisasi kehidupan. Penyampaian materi dengan ceramah justru 
membuat siswa sulit untuk memahami, karena materi ini akan menjadi bersifat abstrak. Riyana \& Susilana (2009: 7) menyatakan bahwa pengetahuan yang diperoleh siswa semakin abstrak jika guru menjelaskan secara verbal, sehingga ceramah menjadi tidak efektif untuk digunakan. Hal ini juga berarti bahwa siswa hanya akan mendengar penjelasan guru tanpa memahami makna yang terkandung didalamnya.

Salah satu cara untuk mengatasi kesulitan siswa dalam memahami materi sistem organisasi kehidupan adalah dengan menggunakan multimedia pembelajaran interaktif. Menurut Riyana \& Susilana (2009: 9), multimedia pembelajaran interaktif bermanfaat untuk memperjelas pesan yang disampaikan agar tidak terlalu verbalistis dan mampu membangkitkan motivasi siswa dalam belajar. Penyampaian materi melalui multimedia pembelajaran interaktif juga membantu siswa memahami konsep yang disampaikan. Hal ini juga didukung oleh Arsyad (2011) dan Handika (2012) yang menyatakan bahwa penggunaan multimedia pembelajaran interaktif dapat membantu keefektifan proses pembelajaran dan penyampaian pesan serta membangkitkan minat dan motivasi siswa.

Salah satu bentuk multimedia pembelajaran interaktif adalah berbasis game edukasi dengan menggunakan perangkat komputer. Perangkat komputer sangat cocok untuk digunakan sebagai multimedia pembelajaran interaktif pada saat ini, karena perangkat ini telah dikenal siswa. Perangkat ini mampu menampilkan gambar serta animasi secara lebih menarik yang tidak dimiliki oleh buku teks biasa.

Penggunaan multimedia interaktif dengan game edukasi dapat meningkatkan motivasi siswa untuk mempelajari suatu materi (Papastergiou, 2008: 1). Gros (2007: 23) juga menyatakan bahwa pembelajaran berbasis game dapat digunakan dalam pembelajaran sehingga lebih menarik dan efektif. Hal tersebut juga didukung oleh Forest dkk (2012: 85) \& Inoue dkk (2014: 285) yang menyatakan bahwa game memiliki potensi untuk dikembangkan dalam pembelajaran dan bekerja pada kemampuan kognitif siswa. Hung dkk (2011) menyatakan bahwa pembelajaran dengan game edukasi mampu meningkatkan prestasi belajar siswa. Multimedia pembelajaran interaktif berbasis game edukasi juga sangat efektif diterapkan pada pembelajaran dan layak digunakan sebagai media pembelajaran IPA terpadu (Dewi dkk, 2013; Haryani dkk: 2014). Berdasarkan hal tersebut disimpulkan bahwa pembelajaran yang menggunakan multimedia pembelajaran interaktif berbasis game edukasi membuat pembelajaran lebih menarik dan efektif diterapkan pada siswa.

Penelitian sebelumnya pada materi sistem organisasi kehidupan yaitu oleh Megahati \& Ramanda (2011) berupa media interaktif tetapi belum disajikan dalam bentuk game. Hasilnya didapatkan bahwa media tersebut valid dan praktis digunakan. Siswa menjadi lebih termotivasi dan tertarik untuk mempelajari materi dengan media pembelajaran interaktif tersebut. Astuti (2015) juga melakukan penelitian media pembelajaran interaktif, namun dengan media berupa kartu. Siswa melakukan pembelajaran dengan berkelompok. Hasil yang didapat adalah siswa lebih aktif dan tujuan pembelajaran dapat tercapai dengan maksimal.

Materi sistem organisasi kehidupan memiliki kelemahan dalam pembelajarannya. Materi sel, jaringan, organ, dan sistem organ adalah materi yang tidak dapat diamati secra langsung sehingga memerlukan media untuk dipelajari siswa. Materi tersebut memerlukan bantuan gambar, animasi, dan video pembelajaran agar mudah dipahami oleh siswa. Materi hakikat sistem organisasi kehidupan memerlukan gambar untuk memperjelas urutan unit- 
unit kehidupan, dan materi organisme memerlukan gambar untuk memberikan contohcontoh organisme.

Penggunaan multimedia dapat memeperjelas materi yang tidak dapat diamati secara langsung oleh siswa. Melalui gabungan teks, grafik, suara, animasi, dan video dapat memperjelas materi tersebut, terutama materi sel dan organel penyusunnya (Katrin \& Pribadi, 2004: 20). Multimedia dengan memasukkan unsur game didalamnya juga dapat memotivasi siswa untuk belajar (Lakoro, 2009: 15). Kelebihan utama multimedia game edukasi adalah pada visualisasi dari permasalahan nyata. Menurut Hutagalung dkk (2009: 3) game edukasi unggul dalam beberapa aspek jika dibandingkan dengan metode pembelajaran konvensional. Salah satu keunggulan yang signifikan adalah adanya animasi yang dapat meningkatkan daya ingat sehingga anak dapat menyimpan materi pelajaran dalam waktu yang lebih lama dibandingkan dengan metode pengajaran konvensional.

Berdasarkan hal tersebut, maka penggunaan multimedia pembelajaran interaktif berbasis game edukasi bisa menjadi solusi dalam mengatasi kesulitan pada materi sistem organisasi kehidupan. Hasil penelusuran di lapangan ternyata juga belum ditemukan penelitian multimedia interaktif berbasis game edukasi yang khusus memuat materi sistem organisasi kehidupan. Berdasarkan hal tersebut maka hal ini menjadi sebuah peluang untuk dikembangkan.

\section{Metode}

Penelitian ini menggunakan model pengembangan modifikasi 4-D. Model pengembangan ini dikembangkan oleh Thiagarajan dkk (1974: 5). Langkah-langkah yang dilakukan yaitu define, design, develope, dan disseminate. Penelitian yang akan dilakukan kali ini tidak menerapkan langkah-langkah 4-D secara keseluruhan. Langkah yang ditempuh hanya pada tahap define (pendefinisian), design (perancangan), dan develope (pengembangan), sedangkan disseminate (penyebaran) tidak dilakukan karena penelitian ini hanya terbatas sampai melakukan validasi dan uji keterbacaan saja.

Tingkat kelayakan multimedia pembelajaran yang dikembagkan diketahui melalui uji validasi dan uji keterbacaan. Uji validasi terdiri atas validasi media dan validasi materi yang terdiri atas validasi konsep materi dan kesesuaian pembelajaran. Data didapatkan melalui angket yang diisi oleh validator dan siswa sebagai subjek uji keterbacaan. Teknik analisis yang digunakan yaitu teknik analisis data deskriptif oleh Arikunto (2013). Perhitungan pada angket kali ini dengan memberikan skor satu hingga lima pada skala Linkert untuk validasi media, kesesuaian pembelajaran dan uji keterbacaan, sedangkan untuk validasi materi menggunakan skor nol sampai satu pada skala Guttman. Rumus yang digunakan adalah sebagai berikut:

$$
P=\frac{\sum x}{n} x 100 \%
$$

\footnotetext{
Keterangan:

$\mathrm{P} \quad=$ Persentase

$\Sigma \mathrm{x} \quad=$ jumlah jawaban tiap responden dari tiap

item yang dinilai

$\mathrm{n} \quad=$ jumlah total skor jawaban jika seluruh

responden menjawab skor maksimal
} 
Validasi media dilakukan oleh ahli media yang terdiri atas satu orang dosen Fisika UM dan satu orang guru IPA SMP Kartika IV-8 Malang, sedangkan validasi materi dilakukan oleh ahli materi yaitu satu orang dosen Biologi UM. Uji keterbacaan pada kelompok kecil dilakukan pada 15 siswa kelas VIII SMP Kartika IV-8 yang telah menempuh materi sistem organisasi kehidupan. Kriteria kelayakan hasil uji validasi dan uji keterbacaan untuk tiap angket, yaitu $81 \%-100 \%$ untuk kriteria sangat layak, 61\%-80\% untuk kriteria layak, 41\%$60 \%$ untuk kriteria cukup layak, $21 \%-40 \%$ untuk kriteria tidak layak, dan persentase $0 \%$ 20\% untuk kriteria sangat tidak layak (Riduwan, 2004:89).

\section{Hasil dan Pembahasan}

\subsection{Deskripsi Produk}

Produk yang dihasilkan berupa aplikasi multimedia pembelajaran interaktif pada materi sistem organisasi kehidupan berbasis game edukasi. Aplikasi ini dapat dioperasikan pada perangkat komputer. Multimedia tersebut terdiri atas lima bagian utama yaitu halaman awal, halaman petunjuk, halaman game, halaman soal evaluasi, dan halaman pengembang.

Siswa yang akan menggunakan multimedia ini harus membaca petunjuk penggunaan game yang terdapat pada halaman petunjuk. Setelah siswa membaca petunjuk maka siswa dapat mempelajari materi sistem organisasi kehidupan pada halaman game. Materi yang disajikan dibagi atas enam sub materi yaitu hakikat sistem organisasi kehidupan, sel, jaringan, organ, sistem orgam, dan organisme. Berikut merupakan gambar tampilan awal multimedia pembelajaran seperti Gambar 1 berikut ini.

\section{Gambar 1 Tampilan Halaman Awal}

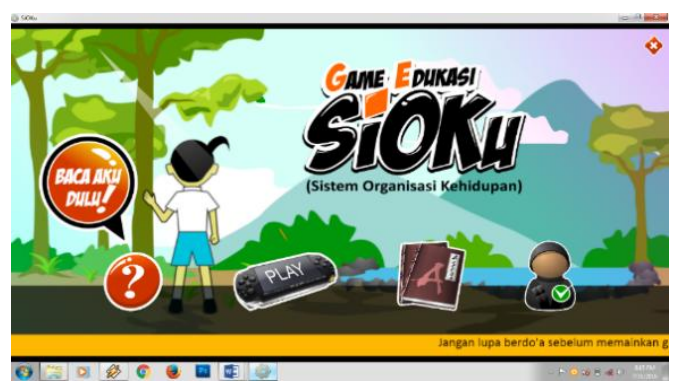

Siswa yang telah selesai menjalankan game ini dapat mengerjakan soal evaluasi. Bagian ini terdiri atas 25 soal tentang sistem organisasi kehidupan. Setelah selesai mengerjakan soal evaluasi siswa akan mengetahui nilai yang diperoleh beserta soal yang benar dan soal yang salah. Berikut merupakan gambar tampilan soal evaluasi seperti pada Gambar 2 berikut ini. 


\section{Gambar 2 Tampilan Soal Evaluasi}

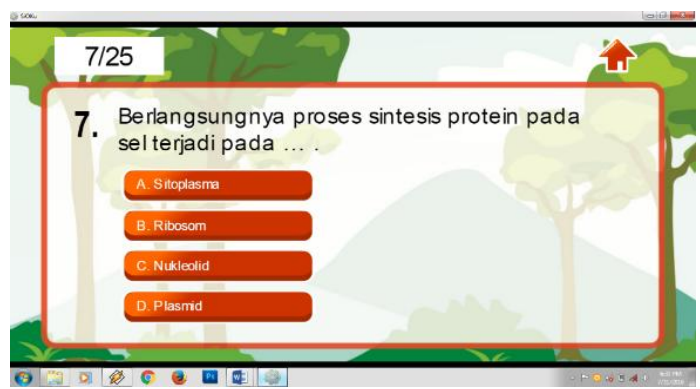

\subsection{Hasil Analisis Data}

Analisis data diperoleh dari data validasi dan uji keterbacaan. Validasi media dilakukan oleh satu orang dosen Fisika UM dan satu orang guru IPA SMP Kartika IV-8 Malang, validasi konsep materi dan kesesuaian materi pembelajaran oleh satu orang dosen Biologi UM. Uji keterbacaan dilakukan pada 15 siswa kelas VIII-C SMP Kartika IV-8 Malang. Hasil validasi dan uji keterbacaan yang diperoleh seperti pada Tabel 1 berikut.

Tabel 1 Kelayakan Multimedia Berdasarkan Validas dan Uji Keterbacaan

\begin{tabular}{lll}
\hline Aspek & Persentase (\%) & Kriteria \\
\hline Media & 85,4 & Sangat Layak \\
\hline Konsep materi & 100,0 & Sangat Layak \\
\hline Kesesuaian pembelajaran & 85,0 & Sangat Layak \\
\hline Uji keterbacaan & 90,4 & Sangat Layak \\
\hline
\end{tabular}

Berdasarkan hasil angket diperoleh persentase rata-rata validasi media 85,4\%, validasi konsep materi 100\%, validasi kesesuaian pembelajaran $85 \%$, dan uji keterbacaan $90,4 \%$. Sehingga semua aspek yang dinilai pada multimedia pembelajaran interaktif yang dikembangkan telah memenuhi kriteria sangat layak digunakan. Berdasarkan hal tersebut maka multimedia pembelajaran interaktif pada materi sistem organisasi kehidupan berbasis game edukasi telah memenuhi kriteria sangat valid dan sangat layak untuk digunakan pada pembelajaran IPA.

Multimedia pembelajaran game edukasi yang dikembangkan ini memiliki beberapa kelebihan dan kekurangan. Kelebihan yang terdapat pada multimedia ini yaitu: (1) tampilan dan animasi yang menarik sehingga siswa lebih termotivasi untuk menggunakannya, (2) unsur game yang terdapat pada multimedia ini dapat memberikan motivasi untuk belajar pada siswa, dan (3) multimedia ini dapat digunakan oleh siswa untuk belajar kapan saja dan dimana saja selama terdapat perangkat pendukung komputer. Kelemahan yang terdapat pada multimedia ini yaitu: (1) pengembangan multimedia belum diterapkan dalam pembelajaran secara menyeluruh sehingga tidak dapat diketahui keefektifannya dan (2) hanya dilakukan uji keterbacaan kelompok kecil sehingga belum diketahui efektifitas multimedia pembelajaran yang dikembangkan dibandingkan dengan yang tidak belajar menggunakan multimedia ini 


\section{Simpulan}

\subsection{Simpulan}

Hasil dari penelitian dan pengembangan ini adalah aplikasi multimedia pembelajaran yang dapat dijalankan pada perangkat komputer. Tingkat kelayakan produk yang didapatkan yaitu validasi media sebesar $85,4 \%$, validasi konsep materi $100 \%$, validasi kesesuaian pembelajaran sebesar $85 \%$, dan uji keterbacaan sebesar $90,4 \%$. Berdasarkan hasill tersebut dapat disimpulkan bahwa multimedia pembelajaran interaktif pada materi sistem organisasi berbasis game edukasi kehidupan yang dikembangkan sudah valid dan sangat layak digunakan pada pembelajaran IPA SMP.

\subsection{Saran}

Saran yang dapat diberikan pada penelitian pengembnagan ini yaitu sebagai berikut: (1) penggunaan multimedia pembelajaran oleh siswa tetap harus mendapatkan bimbingan dan arahan dari guru ketika akan digunakan oleh siswa baik di kelas maupun diluar kelas secara mandiri, (2) dilakukan diseminasi agar produk yang dihasilkan dikenal dan diterima secara luas oleh pengguna terutama guru dan siswa, dan (3) dilakukan penelitian serupa pada materi yang IPA yang lain untuk mengisi kekurangan multimedia pembelajaran pada materi IPA yang lain.

\section{Daftar Rujukan}

Arikunto, S. (2013). Prosedur penelitian: Suatu pendekatan praktik. Rineka cipta.

Arsyad, A. (2011). Media pembelajaran.

Astuti, S. W. B. (2016). Penggunaan Media Pembelajaran Interaktif Pokemon Card Untuk Meningkatkan Ketrampilan Proses Belajar Materi Organisasi Kehidupan Siswa Kelas VII. Jurnal Scientia Indonesia, 1(1), 23-28.

Boeker, M., Andel, P., Vach, W., \& Frankenschmidt, A. (2013). Game-based e-learning is more effective than a conventional instructional method: a randomized controlled trial with third-year medical students. PloS one, 8(12), e82328.

Gros, B. (2007). Digital games in education: The design of games-based learning environments. Journal of research on technology in education, 40(1), 23-38.

Handhika, J. (2012). Efektivitas media pembelajaran IM3 ditinjau dari motivasi belajar. Jurnal Pendidikan IPA Indonesia, 1(2).

Heriyanto, A., \& Haryani, S. (2014). Pengembangan multimedia pembelajaran interaktif berbasis education game sebagai media pembelajaran kimia. Chemistry in Education, 3(1).

Inoue, H. Kaneko, K., Kawaza, S., Nishimoto, Y., Oguma, T., Tamari, H., Sugimura, R., Takano, S., Watanabe, K., \& Yoshida, M., (2014). Mobile Games for Learning Bacteriology, 10th International Conference Mobile Learning 2014, (Online), (http://File.eric.ed.gov), diakses 8 September 2015.

Katrin, Y., \& Pribadi, B. A. (2004). Media Teknologi. Jakarta: Pusat Penerbitan Universitas Terbuka Departemen Pendidikan Nasional.

Lakoro, R. (2009). Mempertimbangkan peran permainan edukasi dalam pendidikan di Indonesia. In Seminar Industri Kreatif ITS Tahun.

Mariana, I. M. A., \& Praginda, W. (2009). Hakikat IPA dan pendidikan IPA. Bandung: PPPPTK IPA.

Megahati, S. N., \& Ramanda, W. (2011). Pengembangan Media Interaktif pada Materi Organisasi Kehidupan untuk Sekolah Menengah Pertama (SMP), (Online), (http://ejournal-s1.stkip-pgri-sumbar.ac.id), 30 Oktober 2015. 
Papastergiou, M. (2009). Digital game-based learning in high school computer science education: Impact on educational effectiveness and student motivation. Computers \& education, 52(1), 1-12.

Perlman, D., Forrest, G. J., \& Pearson, P. J. (2012). Nintendo Wii: Opportunities to put the education back into physical education.

Riduwan. 2004. Belajar Mudah Penelitian untuk Guru-Karyawan dan Peneliti Pemula. Bandung: Alfabeta.

Susanto, S., Dewi, N. R., \& Irsadi, A. (2013). Pengembangan multimedia interaktif dengan education game pada pembelajaran IPA terpadu tema cahaya untuk siswa SMP/MTs. Unnes Science Education Journal, 2(1).

Susilana, R., \& Riyana, C. (2009). Media Pembelajaran: Hakikat. Pengembangan, Pemanfaatan dan Penilaian, Bandung.

Tapilouw, F. S., \& Juanda, E. A. (2009). HOW INTERACTIVE MULTI MEDIA (IMM) AFFECTED STUDENTS'COGNITION IN LEARNING BIOLOGY AT THE MIDDLE AND HIGHER EDUCATION LEVEL?. In Procedding International Conference on Rural Information and Communication Technology (pp. 209215).

Thiagarajan, S. (1974). Instructional development for training teachers of exceptional children: A sourcebook.

Trianto, S. P., \& Pd, M. (2007). Model Pembelajaran Terpadu dalam Teori dan Praktek. Jakarta: Prestasi Pustaka.

Yien, J. M., Hung, C. M., Hwang, G. J., \& Lin, Y. C. (2011). A game-based learning approach to improving students' learning achievements in a Nutrition course. Turkish Online Journal of Educational Technology-TOJET, 10(2), 1-10. 